\title{
Clinical response to the canakinumab in crohn's disease related artrhritis
}

\author{
Zübeyde Gündüz ${ }^{1}$, Ruhan Düşünsel ${ }^{1}$, Duran Aslan², Betül Sözeri ${ }^{1}$, Ayşenur Paç Kısaarslan ${ }^{\text {** }}$ \\ From 21st European Pediatric Rheumatology (PReS) Congress \\ Belgrade, Serbia. 17-21 September 2014
}

\section{Introduction}

Crohn's disease $(\mathrm{CD})$ is an inflammatory disorder of the gastrointestinal (GI) tract that is both chronic and relapsing. In addition to affecting the GI tract, $\mathrm{CD}$ has several extra-intestinal manifestations. Arthritis is a common, occurring in approximately $30 \%$ of CD patients. Here we report a patient with $\mathrm{CD}$ who had treatment resistant artrthritis.

\section{Results}

A 4 years old girl was admitted because of right hip pain. When she was 1 year old was diagnosed with Crohn's disease and taken sulfasalazine and corticosteroid. She had septic arthritis in her right hip one year ago. On admission, we have found pain and limitation in right hip. Also she was growth retardation. In her laboratory findings, acute phase reactants were elevated (white blood cells :20 $500 / \mathrm{mm}^{3}$, Thrombocyte : $596000 / \mathrm{mm}^{3}$, ESH:120 mm/h, CRP 50,2 mg/L). She had also anemia (Hemoglobine : $8 \mathrm{gr} / \mathrm{dl}$ ). We found ANA and HLA B27 were negative. We detected arthritis in right hip joint and bilateral sacroiliac joints in her MRI. Glucocorticoids and methotrexate (MTX) was started effectively; however, the patient did not reach complete remission. Therefore etanercept was added her therapy. We found homozygote MEFV mutation (M694V/M694V) and cholchine was added in her therapy.

After one year, a severe arthritis flare occurred, with an aggressive polyarticular course. In consideration of the lack of control obtained through the etanercept administration. We then decided to switch from etanercept to infliximab), which was administered at 7 dose. Despite this therapy, symptoms and laboratory findings did not regress.
We started canakinumab $(2 \mathrm{mg} / \mathrm{kg} / \mathrm{month})$ therapy. Her arthritis was recovery on canacinumab in 3 months.

\section{Conclusion}

Interleukin-1 (IL-1) is a highly active pro-inflammatory cytokine that lowers pain thresholds and damages tissues. Monotherapy blocking IL-1 activity in autoinflammatory syndromes results in a rapid and sustained reduction in disease severity, including reversal of inflammationmediated loss of sight, hearing and organ function.

The pathogenesis of CD may be mediated by IL-1, and canakinumab may be useful when this disorder is unresponsive to more conventional treatments.

\section{Disclosure of interest}

None declared

\section{Authors' details}

${ }^{1}$ Pediatric Rheumatology, Erciyes University faculty of medicine, Kayseri, Turkey. ${ }^{2}$ Pediatric Gastroenterology, Erciyes University faculty of medicine, Kayseri, Turkey.

Published: 17 September 2014

doi:10.1186/1546-0096-12-S1-P346

Cite this article as: Gündüz et al: Clinical response to the canakinumab in crohn's disease related artrhritis. Pediatric Rheumatology 2014 12(Suppl 1):P346. 